\title{
Potensi Aloe Vera sebagai Antiviral dan Immunostimulan di Masa Pandemi Covid-19: Review Article
}

\author{
Wawan Wijaya ${ }^{1}$, Riska Ammalia ${ }^{2}$, Didi Wirdiana ${ }^{3}$, Arya Yudanta ${ }^{4}$, Masfufatun ${ }^{5 *}$ \\ Fakultas Kedokteran, Universitas Wijaya Kusuma Surabaya, Indonesia ${ }^{1,2,3,4}$ \\ Departemen Biokimia, Fakultas Kedokteran, Universitas Wijaya Kusuma Surabaya, \\ Indonesia ${ }^{5}$ \\ *e-mail: masfufatun@uwks.ac.id
}

\begin{abstract}
Abstrak
Aloe Vera merupakan salah satu jenis tanaman obat-obatan yang semakin populer, tidak hanya bermanfaat untuk kecantikan tapi juga untuk kesehatan. Tujuan dari artikel ini yaitu membahas kandungan yang terdapat pada Aloe Vera sebagai antiviral dan imunostimulan. Metode yang digunakan oleh penulis dalam artikel ini menggunakan metode studi pustaka/literatur review, dengan mengumpulkan beberapa sumber tertulis melalui pencarian data yang di akses melalui Google sholar dan Science direct. Hasil dari analisis data menunjukkan bahwa Aloe Vera mengandung senyawa aktif yang memiliki efek biologik yaitu Mucopolysaccharides (MPS) salah satunya adalah polisakarida Acemannan yang mengandung bahan aktif Acetylated mannose yang masuk dalam golongan sakarida dan mempunyai fungsi untuk meningkatkan sistem kekebalan tubuh (immunostimulan). Selain itu Aloe Vera memiliki kandungan antraquinon dan juga aloe emodin yang berfungsi sebagai antiviral untuk mencegah masuknya virus ke dalam tubuh. Berdasarkan hasil review artikel ini maka dapat disimpulkan bahwa Aloe Vera bisa sebagai antiviral dan immunostimulan karena memiliki kandungan Acemannan, antraquinon dan aloe emodin. Dengan mengetahui informasi ini diharapkan masyarakat bisa memanfaatkan Aloe Vera yang berada di lingkungan sekitar sebagai bahan pangan selama Pandemi Covid -19.
\end{abstract}

Kata Kunci: Aloe Vera, antiviral, immunostimultan

\section{Potential of Aloe Vera as Antivirus and Immunostimulant during the Covid-19 Pandemic}

\begin{abstract}
Aloe Vera is a type of medicinal plant that is growing in popularity, not only beneficial for beauty but also for health. The purpose of this article is to discuss the content contained in Aloe Vera as an antiviral and immunostimulant. The method used by the author in this article uses the literature review method, by collecting several written sources through data search accessed via Google Sholar. The results of the data analysis show that Aloe Vera contains active compounds that have biological effects, namely Mucopolysaccharides (MPS), one of which is the Acemannan polysaccharide which contains the active ingredient Acetylated mannose which is included in the saccharide class and has a function to increase the immune system (immunostimulants). In addition, Aloe Vera contains anthraquinone and aloe emodin which functions as an antiviral to prevent viruses from entering the body. Based on the results of this review article, it can be concluded that Aloe Vera can be an antiviral and immunostimulant because it contains Acemannan, antraquiono and aloe emodin. By knowing this information, it
\end{abstract}


Potensi Aloe Vera sebagai Antiviral dan Immunostimulan di Masa Pandemi Covid-19: Review... Wawan Wijaya, Riska Ammalia, Didi Wirdiana, Arya Yudanta, Masfufatun

is hoped that the public can use Aloe Vera in the surrounding environment as food during the Covid-19 Pandemic.

Keywords: Aloe Vera, antiviral, immunostimultan

\section{PENDAHULUAN}

Pada tahun 2020, Indonesia terkena dampak pandemi Covid-19. World Health Organization (WHO) menjelaskan bahwa Coronavirus disease (Covid-19) adalah salah satu virus yang dikatakan cukup berbahaya dikarenakan virus tersebut secara langsung menginfeksi sistem pernapasan pada penderitanya. Selain itu, Coronavirus disease (Covid-19) termasuk dalam kategori zoonotic yaitu ditularkan antara hewan dengan manusia (Hanoatubun, 2020)

Berdasarkan Kementerian Kesehatan Indonesia, awal munculnya kasus Coronavirus disease (Covid-19) bermula pada tanggal 30 desember 2019 yang terletak di China khususnya pada Kota Wuhan sehingga Wuhan Municipal Health Committee mengeluarkan pernyataan "urgent notice on the treatment of pneumonia of unknown cause". Dalam beberapa bulan kemudian penularan virus corona tersebut sangat cepat sampai ke lintas Negara, hal ini menyebabkan 188 negara telah mengkonfirmasi terkena virus corona (Hanoatubun, 2020).

Tingginya tingkat kematian akibat Coronavirus disease (Covid-19) disebabkan oleh dua faktor diantaranya penyakit bawaan atau komplikasi dan yang paling penting yaitu sistem kekebalan tubuh yang lemah. Sejak awal munculnya kasus Coronavirus disease (Covid-19) pemerintah menghimbau kepada masyarakat untuk lebih rajin mencuci tangan dan menjaga sistem imunitas agar masyarakat tidak mudah terkena virus yang ada di lingkungan sekitar dan mencegah terjadinya penyebaran virus, Akan tetapi himbauan yang telah dikeluarkan oleh pemerintah tersebut telah diabaikan bahkan dianggap remeh oleh masyarakat. Salah satu tim pakar gugus tugas penanganan Coronavirus disease (Covid19), Wiku Adisasmito mengatakan bahwa penyakit Coronavirus disease (Covid-19) dapat sembuh dengan sendirinya atau selflimiting disease. Menteri Kesehatan Terawan yaitu Agus Putranto juga menyatakan bahwa memiliki sistem imun yang kuat adalah salah satu cara untuk melawan virus, dimana hal ini juga berlaku untuk Coronavirus disease (Covid-19)(IIpaj and Nurwati, 2020)

Virus dapat berkembang biak dengan mudah dalam tubuh makhluk hidup. Ketika kekebalan tubuh menurun 
maka tubuh akan lebih mudah terinfeksi. Oleh karena itu untuk mencegah masuknya virus khususnya Coronavirus disease (Covid-19) yaitu dengan cara meningkatkan daya tahan tubuh (Amalia, et al., 2020). Kekebalan tubuh bersifat dinamis bisa naik atau turun karena dipengaruhi oleh beberapa faktor salah satunya yaitu faktor usia. Semakin bertambah usia seseorang maka sistem tubuh akan semakin tidak stabil. Hal ini terjadi karena pada usia tersebut seseorang sudah memiliki tanggung jawab yang besar sehingga sering mengabaikan kesehatan dan jarang melakukan aktivitas olahraga. Menurut Prof iris, Imunostimulan dapat meningkatkan sistem imun, dengan cara mengaktifkan berbagai elemen dan mekanisme yang berbeda. Adapun fungsi dari imunostimulan adalah meningkatkan pertahanan alamiah yang berada di dalam tubuh untuk mencegah berbagai infeksi virus dan bakteri serta penyakit lainnya yang dapat menurunkan sistem imun (Amalia, Irwan and Hiola, 2020).

Aloe Vera sering kita kenal dengan nama tanaman lidah buaya merupakan salah satu tanaman di Indonesia yang dapat berperan sebagai imunostimulan dan antiviral, hal ini dibuktikan dengan adanya berbagai hasil penelitian yang menunjukkan bahwa Aloe Vera ternyata memiliki berbagai efek fisiologis terhadap tubuh, diantaranya yaitu antiinflamasi, antioksidan, antikanker, antidiabetes, antivirus dan mengaktivasi makrofag (Grover, Yadav and Vats, 2002; Xiao et al., 2007; Xu et al., 2008). Secara umum pemberian Aloe Vera menunjukkan peningkatan aktivitas fagositosis dan memproliferasi sistem retikuloendotelial (Im et al., 2005). Selain itu, Aloe Vera juga terbukti mampu menstimulasi imunitas seluler maupun humoral serta menstimulasi proliferasi stem cell hematopoietic (Im et al., 2005; Boudreau and Beland, 2006).

Berdasarkan latar belakang di atas, sehubungan dengan pandemi Covid-19 yang ada di Indonesia, maka penulis tertarik untuk menganalisis lebih lanjut mengenai "Potensi Aloe Vera sebagai antiviral dan imunostimulan di masa pandemi Covid -19". Tujuan review artikel ini adalah membahas kandungan yang terdapat pada Aloe Vera yang berfungsi sebagai antiviral dan imunostimulan. Dengan mengetahui informasi ini, diharapkan masyarakat dapat memanfaatkan Aloe Vera sebagai usaha untuk mencegah masuknya virus ke dalam tubuh sehingga bisa memutus penyebaran Covid-19. 
Potensi Aloe Vera sebagai Antiviral dan Immunostimulan di Masa Pandemi Covid-19: Review... Wawan Wijaya, Riska Ammalia, Didi Wirdiana, Arya Yudanta, Masfufatun

\section{METODE}

Metode yang digunakan oleh penulis dalam artikel ini menggunakan metode studi pustaka/literature review. Teknik pengumpulan data yang digunakan penulis yaitu melakukan penggalian informasi berdasarkan beberapa sumber tertulis berupa artikel penelitian yang penulis akses melalui Google scholar \& Science
Direct. Selain itu, beberapa jurnal serta dokumen-dokumen terkait dengan informasi tersebut juga digunakan oleh penulis guna mendapatkan informasiinformasi yang lebih akurat pada artikel ini. Tahapan literauer review dapat dilhat pada Gambar 1.

Tahapan dalam literatur review adalah:

Gambar 1. Tahapan Literatur Review

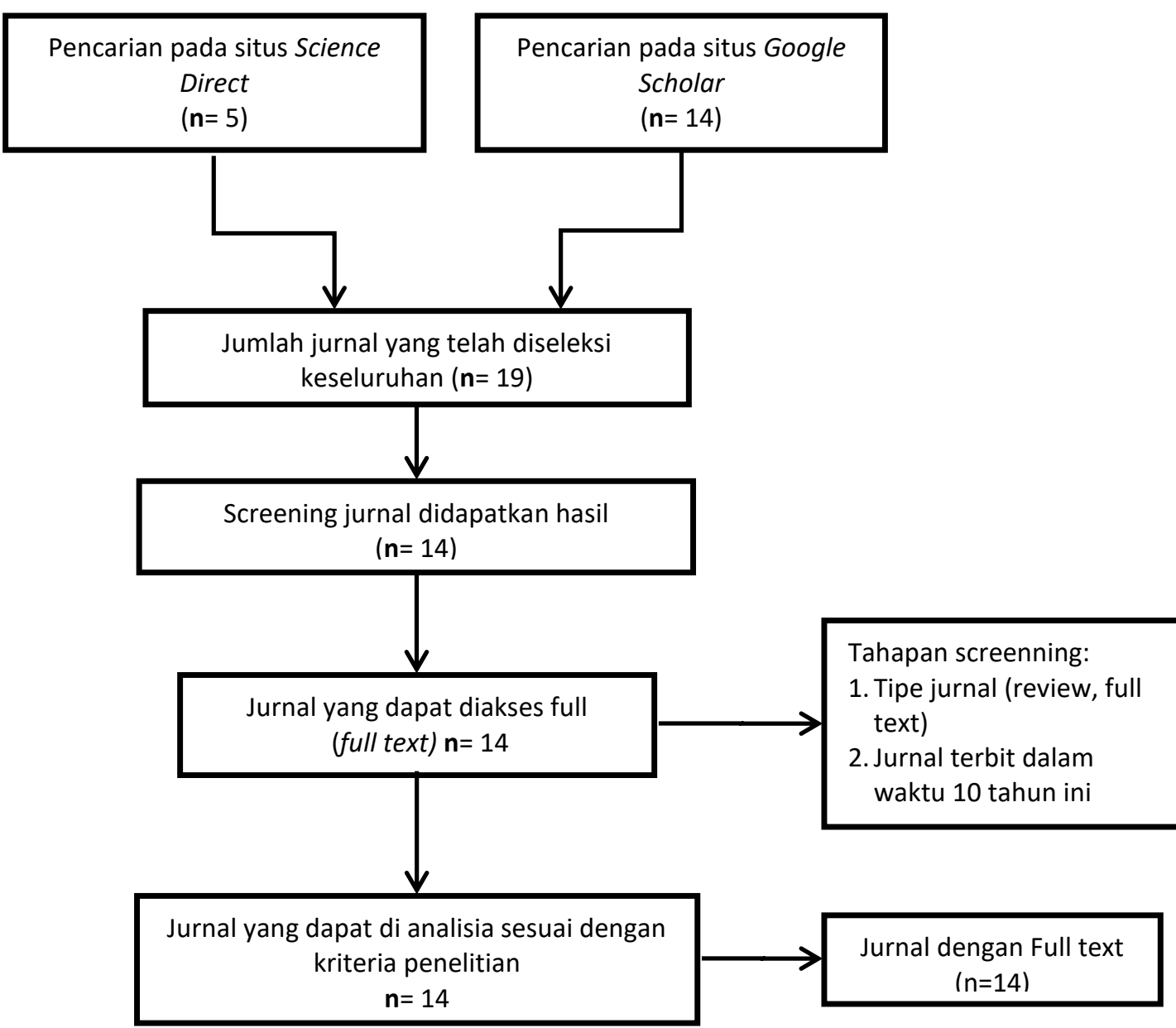

Keterangan: n: adalah jumlah hasil yang dicari pada Science Direct maupun Google Scholar

PEMBAHASAN

Kandungan Tanaman Lidah Buaya (Aloe

Vera)
Salah satu tanaman yang paling populer dan sering digunakan di dunia medis adalah aloe vera. Biasanya tanaman 
ini digunakan sebagai tanaman obat untuk tatalaksana penyakit kulit, metabolic, kardiovaskular, dan kanker. Kandungan dari aloe vera yaitu polisakarida yang berfungsi sebagai imunomodulasi, antimikroba, antivirus, antikanker dan antiinflamasi. Acemannan atau $\beta$-(1,4)-acetylated soluble polymannose
(Gambar 2) adalah polisakarida bioaktif utama yang didapatkan dari ektraksi kulit dan gelnya. Acemannan merupakan salah satu jenis penyimpanan dari asetil glukomanan yang terletak di protoplas dari sel parenkim yang mengandung beberapa polisakarida di dinding matriks sel (Liu et al., 2019).

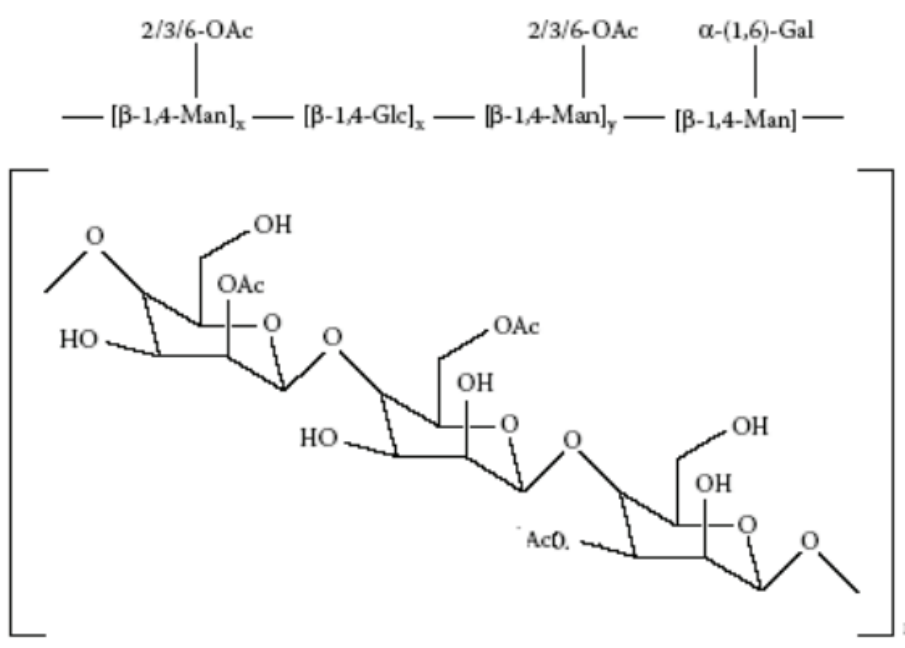

Gambar 2. Struktur mucopolysaccharide acemannan (Gerardo et all, 2014)

Kandungan aloe vera lainnya yang mempunyai 9 jenis senyawa yaitu antrakuinon, senyawa tersebut diantaranya Anthraquinones/anthrones (aloe-emodin, aloetic-acid, anthranol, barbaloin, isobarbaloin, emodin, ester of cinnamic acid); chromones (8-C-glusoly-(2'O cinnamoly)-7-O-methlyaloediol $A, 8-C$ glucosyl-(S)-aloesol, $\quad$ 8-C-glucosyl-7-Omethylaloediol A, 8-C-glucosyl-7-0methylaloediol, 8-C-glucosyl-noreugenin, isoaloeresin $D, \quad$ isorabaichromone, neoalosin A), steroids (campesterol, cholesterol, 6-sitosterol), triglycerides; triterpenoids; gibberillin; lignins; potassium sorbate; salicylic acid dan uric acid (Mpiana et al., 2020).

\section{Lidah Buaya (Aloe Vera) sebagai Immunostimulan}

Kandungan aloe vera yaitu acemannan adalah polisakarida utama yang mempunyai efek terapi yang signifikan seperti imunostimulan. Aktivitas acemannan berpengaruh pada sel sel seperti limfosit, makrofag, dan sel dendritik. acemannan dapat meningkatkan respon limfosit terhadap alo antigen (Gambar 3), Dengan mekanisme IL-1 dari 
Potensi Aloe Vera sebagai Antiviral dan Immunostimulan di Masa Pandemi Covid-19: Review... Wawan Wijaya, Riska Ammalia, Didi Wirdiana, Arya Yudanta, Masfufatun

sel inti dibawah proteksi dari alo antigen. Acemannan dari aloe vera secara efektif mengatur kekebalan tubuh terbukti pada penelitian yang dilakukan oleh kumar (2016) menemukan bahwa tingkat mortalitas tikus ketika diinduksi radiasi, secara signifikan menurun ketika di berikan acemannan dengan dosis $150 \mathrm{mg} / \mathrm{kgBB}$ secara oral 7 hari. Ketika tikus diberikan acemannan tersebut selama 7 hari menunjukkan kelangsungan hidup tikus tersebut meningkat sebesar $60 \%$ dan $20 \%$. Hal itu dikarenakan acemannnan dapat meningkatkan regulasi sitokin seperti TNF$\alpha$, IL-1 dan meningkatkan hematopoiesis pada tikus C57 yang disuntik. Selain itu, acemannan mempunyai aktivitas stimulasi yang lebih dominan untuk sel darah putih dan seluleritas limfa pada jumlah absolut limfosit, neutrofil, monosit, pada tikus myelosupresi yang diinduksi radiasi (Liu et al., 2019).

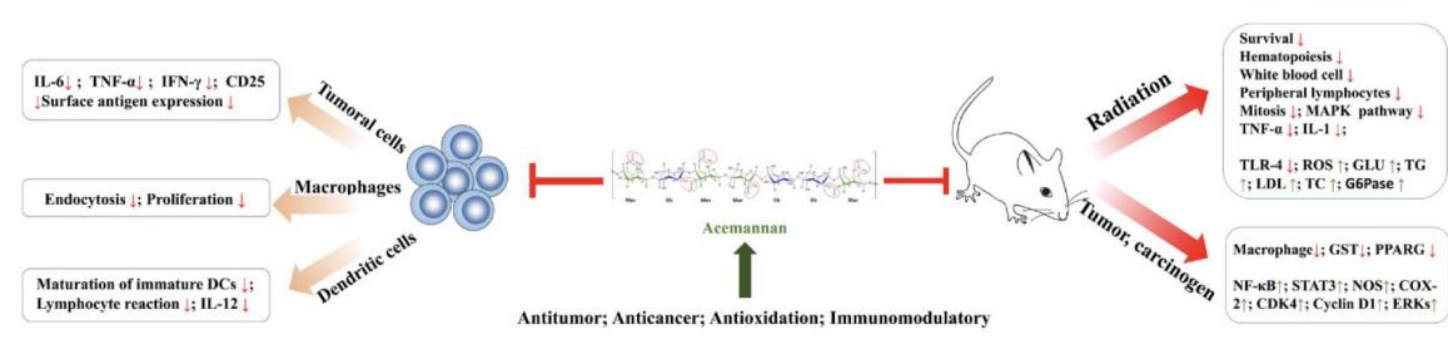

Gambar 3. Efek farmakologi acemannan (Liu et al., 2019).

Lidah Buaya (Aloe Vera) sebagai Antiviral

Aktivitas antivirus dari Aloe vera dan beberapa fitokomia lainnya telah dibuktikan dalam berbagai penelitian lainnya, salah satunya penghambatan proliferasi CMC (Cytomegalovirus) dalam sel yang dilakukan oleh lektin yang diisolasi dari tanaman yang terkandung dalam fraksi gel aloe vera. Selain itu asam chrysophanic dalam aloe vera menghambat sampai $50 \%$ replikasi virus pada virus polio tipe 2 dan 3 pada konsentrasi 0,21 dan 0,02 $\mathrm{g} / \mathrm{ml}$. Tetapi, molekul tersebut tidak memiliki aktivitas antivirus yang signifikan terhadap HSV-1, RRV, CVB4, CVA21 atau HRV-2.
Kandungan acemannan dalam aloe vera menunjukkan aktivitas antivirus in vitro seperti HIV, virus penakit Newcastle, dan virus influenza. Selain itu, acemannan juga menunjukkan penghambatan virus sindrom imunodefisiensi yang didapat secara in vitro, dan acemannan memiliki aktivitas antivirus yang menghambat replikasi virus dan efektivitas dengan memodifikasi glikosilasi sel yang terinfeksi virus dan lapisan glikoprotein virus (Mpiana et al., 2020).

Aktivitas antivirus umumnya dilakukan oleh Antraquinon, namun beberapa kandungan Aloe vera lainnya 
ISSN 1978-2071 (Print); ISSN 2580-5967 (Online) Jurnal Ilmiah Kedokteran Wijaya Kusuma 10(2) : 243-252, September 2021

juga terlibat dalam aktivitas antivirus seperti quercetin, catechin hydrate, kaempferol, acemannan, azidothymidine, acyclovir, aloe - emodin. Selain itu, Kalsium (Ca), Magnesium (Mg), Natrium (Na), Kalium (K), Besi (Fe), Tembaga (Co) dan
Seng (Zn). Zn2+ dapat menghambat coronavirus dan RNA arterivirus dalam aktivitas polymerase in vitro dan Zinc ionophores dapat memblokir replikasi virus ini didalam kultur sel (Tabel. 1) (Mpiana et al., 2020).

Tabel. 1 Aktivitas antivirus oleh kandungan lidah buaya (Mpiana et al., 2020).

\begin{tabular}{|c|c|c|c|}
\hline Jenis - Jenis Virus & Tipe Genom & Molekul & Mode Aksi \\
\hline $\begin{array}{l}\text { Septikemia Rhobdavirus } \\
\text { Viral Hemoragik (VHS) }\end{array}$ & & Aloin & $\begin{array}{l}\text { Penghancuran lapisan ganda } \\
\text { fosfolipid dengan memasukkan ke } \\
\text { dalam amplop virus }\end{array}$ \\
\hline $\begin{array}{l}\text { Virus corona sars } \\
\text { (SARS-CoV1) }\end{array}$ & RNA & & $\begin{array}{l}\text { Aloe-emodin menghambat } \\
\text { pembelahan protease seperti } 3 C \text {, } \\
\text { enzim yang memainkan peran } \\
\text { penting dalam virus replikasi } \\
\text { dengan bertindak pada proses } \\
\text { proteolitik pada tingkat replikase. }\end{array}$ \\
\hline $\begin{array}{l}\text { Herpes virus simpleks } \\
\text { tipe } 1 \text { (HSV-1) } \\
\text { HSV-2 }\end{array}$ & DNA & Aloe-emodin & $\begin{array}{l}\text { Penghambatan biosintesis asam } \\
\text { nukleat mengakibatkan } \\
\text { penghentian sintesis protein }\end{array}$ \\
\hline $\begin{array}{l}\text { Varicella-Zoster virus } \\
\text { (VZV) } \\
\text { Virus influenza }\end{array}$ & & & \\
\hline HIV-1 & RNA & Asemannan & $\begin{array}{l}\text { Acemannan menghambat } \\
\text { glikosilasi protein virus dan } \\
\text { menghambat fusi sel dan } \\
\text { penekanan pelepasan virus }\end{array}$ \\
\hline Virus polio & & Krisofanik Acid & $\begin{array}{l}\text { Molekul ini mencegah penetrasi } \\
\text { virus ke dalam sel, baik translasi } \\
\text { RNA virus atau pembelahan awal } \\
\text { protein virus. }\end{array}$ \\
\hline $\begin{array}{l}\text { Sitomegalovirus (CMV) } \\
\text { Virus papiloma manusia } \\
\text { (HRHPV) }\end{array}$ & DNA & Lektin & $\begin{array}{l}\text { Leptin menghambat proliferasi } \\
\text { CMV dengan mengganggu sintesis } \\
\text { protein. }\end{array}$ \\
\hline
\end{tabular}

\section{KESIMPULAN}

Berdasarkan hasil analisis data dari berbagai data base yang kami dapatkan, kami menyimpulkan bahwa tanaman lidah buaya (Aloe vera) dapat meningkatkan system kekebalan tubuh pada manusia serta dapat berfungsi sebagai antiviral. Hal ini dikarenakan pada tanaman lidah buaya
(Aloe vera) mengandung senyawa aktif, yaitu Acemannan yang memiliki dampak langsung pada sel-sel system imun dan Antraquinon yang memiliki kandungan aloe-emodin yang dapat menganggu selubung virus dengan cara merusak lipid dari virus dan menghambat replikasi virus. Selain itu, lidah buaya (Aloe vera) juga 
Potensi Aloe Vera sebagai Antiviral dan Immunostimulan di Masa Pandemi Covid-19: Review... Wawan Wijaya, Riska Ammalia, Didi Wirdiana, Arya Yudanta, Masfufatun

berpengaruh positif terhadap perubahan hematologi maupun terhadap pemulihan kesehatan. Dengan demikian, dibuatnya artikel ini diharapkan dapat bermanfaat bagi para pembaca khususnya masyarakat Indonesia agar bisa memanfaatkan bahanbahan alami yang ada dilingkungan sekitar selama Pandemi Covid - 19.

\section{UCAPAN TERIMA KASIH}

Kami ucapkan terimakasih kepada

Direktorat Pembelajaran

dan Kemahasiswaan Direktorat Jenderal Pendiikan Tinggi Kementerian Pendidikan, Kebudayaan, Riset, dan Teknologi yang telah memberikan insentif pada karya tulis PKM Artkel Ilmiah (AI) tahun 2021. Kami juga ucapkan terimakasih kepada Fakultas Kedokteran Universitas Wijaya Kusuma Surabaya yang telah membantu memberikan kami sarana untuk mengakses Jurnal berbayar sehingga memudahkan kami untuk mencari berbagai referensi.

\section{DAFTAR PUSTAKA}

Amalia L, Irwan I and Hiola F, 2020. ANALISIS GEJALA KLINIS DAN
PENINGKATAN KEKEBALAN
TUBUH UNTUK MENCEGAH
PENYAKIT COVID-19', Jambura
Journal of Health Sciences and
Research, 2(2): 71-76. doi:
10.35971/jjhsr.v2i2.6134.
Boudreau MD and Beland FA., 2006. An evaluation of the biological and toxicological properties of Aloe barbadensis (miller), Aloe vera', Journal of Environmental Science and Health. Part C, Environmental Carcinogenesis \& Ecotoxicology Reviews, 24(1): 103-154. doi: 10.1080/10590500600614303.

Daniel G, Castro-Ríosc R, González-Hortaa

A, Lara-Ariasb J and Chávez-

Montesa A., 2014. Acemannan, Polisakarida yang Diekstraksi dari Lidah buaya: Sebuah 1217 - 1221 Tinjauan Literatur : NPC, 9(8).

Grover JK, Yadav S and Vats V, 2002. Medicinal plants of India with anti-diabetic potential', Journal of Ethnopharmacology, 81(1), pp. 81-100. doi: 10.1016/s03788741(02)00059-4.

Hanoatubun S, 2020. Dampak Covid - 19 terhadap Prekonomian Indonesia', EduPsyCouns: Journal of Education, Psychology and Counseling, 2(1): 46-153.

Ilpaj SM and Nurwati N., 2020. ANALISIS PENGARUH TINGKAT KEMATIAN AKIBAT COVID-19 TERHADAP KESEHATAN MENTAL MASYARAKAT DI INDONESIA', Focus: Jurnal Pekerjaan Sosial, 
3(1): $\quad$ 16-28. doi:

10.24198/focus.v3i1.28123.

Ima Sun-A, Oha Sun-T, Songa S, Kimb MiRan, D Kimb ong-Seon, et al. 2005 Identification of optimal molecular size of modified Aloe polysaccharides with maximum immunomodulatory activity', International

Immunopharmacology, 5(2): 271279. doi:

10.1016/j.intimp.2004.09.031.

Liu C, Cui Y, Pi F, Cheng Y, Guo Y, et al., 2019. Extraction, Purification, Structural Characteristics, Biological Activities and Pharmacological Applications of Acemannan, a Polysaccharide from Aloe vera: A Review. Journal Molecules, 24.

Mpiana P, Ngbolua K, Tshibangu DSTT, Tshibangu JT, Gbolo BZ, et al. (2020). Lidah buaya (L.) Buram. F. sebagai Potensi Tanaman AntiCOVID-19: Tinjauan Amini tentang Aktivitas Antivirusnya Its: Jurnal Tanaman Obat Eropa, (31)8, pp. 86-93.

Prasetio E, Rachimi and Hermawansyah M, 2018. PENGGUNAAN SERBUK LIDAH BUAYA (Aloe vera) DALAM PAKAN SEBAGAI IMMUNOSTIMULAN TERHADAP
HEMATOLOGI IKAN BIAWAN (Helostoma teminckii) YANG DI UJI TANTANG DENGAN BAKTERI Aeromonas hydrophila', Jurnal Ruaya: Jurnal Penelitian dan Kajian Ilmu Perikanan dan Kelautan, 6(1). doi: 10.29406/rya.v6i1.934.

Xiao B, Guo J, Liu D, Zhang S., 2007. 'Aloeemodin induces in vitro $\mathrm{G} 2 / \mathrm{M}$ arrest and alkaline phosphatase activation in human oral cancer KB cells', Oral Oncology, 43(9), pp. 905-910. doi: 10.1016/j.oraloncology.2006.11.0 02.

Xu F, Liu Y, Zhang Z, Song R, Dong H, 2008. Rapid simultaneous quantification of five active constituents in rat plasma by high-performance liquid chromatography/tandem mass spectrometry after oral administration of Da-Cheng-Qi decoction', Journal of Pharmaceutical and Biomedical Analysis, 47(3), pp. 586-595. doi: 10.1016/j.jpba.2008.02.005

Yuniastuti, A. (2014) 'PERAN PANGAN FUNGSIONAL DALAM MENINGKATKAN DERAJAT KESEHATAN', PROSIDING SEMINAR NASIONAL \& INTERNASIONAL, 0. Available at: 
Potensi Aloe Vera sebagai Antiviral dan Immunostimulan di Masa Pandemi Covid-19: Review... Wawan Wijaya, Riska Ammalia, Didi Wirdiana, Arya Yudanta, Masfufatun

https://jurnal.unimus.ac.id/index.

php/psn12012010/article/view/1

169 (Accessed: 7 July 2021).

Zandi K, Zadeh MA, Sartavi K and Rastian Z, 2007. Antiviral activity of Aloe vera against herpes simplex virus type 2: An in vitro study', African Journal of Biotechnology (ISSN: 1684-5315) Vol 6 Num 15, 6. doi: 10.5897/AJB2007.000-2276. 